\title{
The Opinions of Technology Supported Education of University Students
}

\author{
https://doi.org/10.3991/ijet.v15i23.18779 \\ Vasfi Tugun $(\bowtie)$ \\ Ministery of Education and Culture, North Cyprus, Turkey \\ vasfitugunegmail.com \\ Almira R. Bayanova \\ Kazan Federal University, Kazan, Russia \\ Klavdiya G. Erdyneeva \\ Transbaikal State University, Chita, Russia \\ Nikolay A. Mashkin \\ Plekhanov Russian University of Economics, Moscow, Russia \\ Zavgaria M. Sakhipova \\ Almetyevsk State Oil Institute, Almetyevsk, Russia \\ Liubov V. Zasova \\ I.M. Sechenov First Moscow Medical University, Moscow, Russia
}

\begin{abstract}
The aim of this study is to determine the opinions of university students about technology-supported education. In today's era, technological tools are used in every sector of education. Today, when technologies are rapidly developing, the opinions of students studying at university institutions about technology are very important. As per the outcome of the research, it is important to know the opinions of working people in terms of competencies and attitude towards the technology. The research was carried out in the fall semester of the 2019-2020 academic year with 75 students studying at the Federal University of Kazan (Volga region), the Institute of Legislation and Comparative Law under the Government of the Russian Federation, Plekhanov Russian University of Economics and Sechenov University. As the case study method was adopted in the study, researcher prepared open-ended questions as a data collection tool. In this research, qualitative method was used. According to the results obtained from the research, it was concluded that they did not feel themselves competent in technology, they did not have enough equipment and their schools are not equipped for technology-supported education.
\end{abstract}

Keywords-Technology, education, opinion, student, educational technology, qualitative method 


\section{Introduction}

As the technology is rapidly increasing, with the close relationship, the increased knowledge with the effect of global age has also been reflected in the technology. As the technology is developing day by day, it has a more important place in our lives. Using technology has become a necessity rather than a luxury. In today's era, to use technology in effective manner, it has become important to gain knowledge, habits, and attitudes to understand technology and benefit from its [7]. In our age, it is important to acquire skills like selection analysis, synthesis, and organization of information resources [8].

With the development of technology, the concept of informatics has emerged. Informatics is defined as a structure formed by the combination of information and communication words. The formation, use, and access of information are of great importance. In today's age of technology, communication must be good for informatics to be realized. For this reason, the concept of information technologies has emerged. Information technologies cover all developments in which information is in communication $[23,24,25,28,29]$.

If we look at the areas where we use informatics in our lives, a few of them are as follows:

- In daily life (listening to music, playing games from tablet phones, etc., watching movies ...)

- In the field of education (using computers / smart boards in lessons, using elearning tools, certificate / diploma programs with the departments opened with distance education, online lessons, fun lecture videos, etc.)

- Health (computed tomography and microsurgery methods in the definition of disease and treatment of patients)

- Transportation (Navigation apps)

- Security (Security cameras and systems)

- Banking and shopping (internet banking, online shopping sites)

- Communication (Video conferences, seminars, speaking, messaging)

Apart from these areas, the use of information technologies is increasing in communication, business, logistics, in short, in all areas [3,21,2,25,28,31,10]. The deficiencies of the teachers about online lessons were revealed. In-service trainings and their competencies can be increased in technology supported trainings $[9,20,6,13,5]$.

Technology has been used in many sectors, but the most common sector is education. Today, rapid changes in the field of technology increase the place of technology in education in parallel [16,27]. There are basic rules for effective learning to take place in the classroom. These rules can be achieved when at least one of studentteacher, student-student, student-content and student-environment interactions can be at a high level [4]. Educational technologies can be used to enable these interactive trainings to communicate. When the studies were examined, it was thought that it is necessary to integrate technology with education in order to make teaching-learning processes more efficient and to raise more qualified individuals for future generations 
[15]. For this reason, the concept of education and technology is included in the learning-teaching process with the name of educational technology.

Application of scientific knowledge about educational technology, how people learn to solve teaching and learning problems. A set of systems of staff, tools, materials, processes and methods to transform teaching-related theories into the most effective and positive practices; behavioral or physical sciences concepts and systematic or systematic strategy applications and techniques derived from other information for solving teaching problems $[12,22,3,34]$. As can be understood from the definitions, educational technology teaching means a systematic and holistic approach to learning processes, and tools and materials emerge as one of the important elements of this process $[18,30]$. Especially in the modern understanding of education, the teacher is the person who plans the education and training processes by taking individual differences into consideration and knows how to achieve the goal by choosing the appropriate tools that should be used in this process. In today's world, where science and technology are rapidly developing, it has become difficult to adopt traditional teaching methods [34].

The use of technology has now been used in schools and other institutions of the society. But still, there is a problem on how technology to be used and its inclusion in the educational programmes $[26,27,33]$. Therefore, in parallel with the developments in technology, new researches were made in educational sciences, students' attitudes towards technological equipment were determined, and importance was given to the formation of education policies and strategies for the rational use of investments. this area $[17,35,32]$.

As technology is playing an important role in every sector. Students studying in universities in different department need to have deep knowledge of advance technologies. Teachers, healthcare professionals, operators, and engineers will be able to predict technology to be used in near future.

\subsection{Purpose of the research}

The main motive to conduct this research was to determine the opinions of the students on the technology. In this general scope, the following questions were asked to the senior students of the university.

For this general purpose, the following questions were sought.

1. What is technology? What is your first perception when it comes to technology?

2. What is your main motive to use technology?

3. Can you explain what technological tools and equipment you have encountered during your education process up to now and their effects on your education?

4. What are the pros and cons of using technological tools and equipment in the education process? 


\section{Method}

One of the qualitative methods, interview method was conducted in the descriptive research. After taking their consent, the opinions of the students were taken with voice recording devices. The answers received from the voice recorders were written in the document, and the students' confirmation was received. Hennink, Hutter, and Bailey [36] stated that the focus of qualitative research is a research model that helps us understand the participants.

\subsection{Research group}

The research was conducted in the fall semester of the 2019-2020 academic year with 75 students from the Federal University of Kazan (Volga region), the Institute of Legislation and Comparative Law under the Government of the Russian Federation, Plekhanov Russian University of Economics and Sechenov University. The demographic information of the university student participating in the study was given in Table 1.

Table 1. Demographic information of the instructors

\begin{tabular}{|l|l|c|}
\hline & & f \\
\hline \multirow{4}{*}{ Gender } & Female & 38 \\
\cline { 2 - 3 } & Male & 37 \\
\cline { 2 - 3 } & Total & 75 \\
\hline
\end{tabular}

\subsection{Data collection tools}

In order to know the opinions of senior university students on the technology, the demographic information form was developed by the researcher. Also, semistructured questionnaire consisting open-ended questions were used as data collection tools. The open-ended questions in the questionnaire were created using the literature and the researchers' own experiences. The questionnaire was first examined by 6 experts ( 1 linguist, 5 computer teachers) experienced in qualitative research, and necessary corrections were made according to their feedback.

\section{$3 \quad$ Results}

\subsection{What is technology? What is to your first perception when it comes to} technology? 
Table 2. Students' views on technology

\begin{tabular}{|l|c|}
\hline & N \\
\hline Novelty & 29 \\
\hline Contact & 24 \\
\hline Easy accessibility & 15 \\
\hline Technology tools & 7 \\
\hline
\end{tabular}

The answers given by the senior university students to the question of "what is technology" are innovation (29), communication (24), easy accessibility (15), technological tools (7). It was seen that students mostly answered the concept of technology as innovation and development to keep up with the times.

Some student views were as follows:

"When I think of technology, the first thing that comes to my mind is innovation. Because technology expresses the developing era, new features and tools. "

"When it comes to technology, what comes to my mind is quick access to information. I can quickly access information thanks to technological tools. Likewise, I maintain my communication with technological tools. "

\subsection{For what purpose do you use technology?}

Table 3. Purpose of using technology

\begin{tabular}{|l|c|}
\hline & N \\
\hline communication & 45 \\
\hline Play game & 18 \\
\hline Information research & 10 \\
\hline Preparing homework & 2 \\
\hline
\end{tabular}

Students were asked the question of what purpose you use technology frequently for. Among the findings of this question, they stated that they mostly used it for communication (45), for the game (18), for obtaining information (10), and when preparing homework (2).

Some of the students' views on this finding were as follows:

"I use technological tools to communicate the most. I use features such as telephone communication, social media usage, and messaging."

"I love playing games. Mobile games are where I spend the most time on my computer and phone."

"While preparing my homework, I frequently use technological tools while doing research on a topic." 
3.3 Can you explain what technological tools and equipment you have encountered during your education process up to now and their effects on it?

Table 4. Technological tools and equipment you have encountered during your education process and their effects on it

\begin{tabular}{|l|l|}
\hline \multicolumn{1}{|c|}{ Theme } & N \\
\hline Computer & 50 \\
\hline Projection instrument & 45 \\
\hline Presentation & 29 \\
\hline Tablet, mobile phone & 15 \\
\hline
\end{tabular}

Findings related to the answers given by the senior university students to the question "Technological tools they have used in education until now" were computer (50), projection device (45), presentation (40), tablet (15). The majority of the students stated that they used computers and projectors. According to the answers of this question, one more question was asked to the students: What the effect of using technological equipment on students is. Almost all of the students answered the question that they were motivated by the lesson (62). There were 35 students who stated that technological tools embody knowledge, made learning easier for them.

Some student views were as follows:

"The technological tools I use the most during my education are computers. I find information by searching the internet using a computer. I prepare homework and presentations on the computer. Even the use of the projection tool is done with the help of computers."

"My teachers' lectures by using a projection device in presentations and video presentations increases my interest in the lesson. By showing them away from the verbal lecture and presenting the application concept, the narrations ensure that the information is permanent."

3.4 What are the benefits and harms of using technological tools and equipment in the education process?

Table 5. Benefits and harms of using technological tools and equipment in the education process

\begin{tabular}{|l|l|}
\hline \multicolumn{1}{|c|}{ Positive (75) } & \multicolumn{1}{c|}{ Negative (8) } \\
\hline Effective learning (32) & Teacher technology shortage (7) \\
\hline Fun content (27) & Distraction (1) \\
\hline Interaction (13) & \\
\hline Self-confidence (3) & \\
\hline
\end{tabular}

There were 75 students who gave positive opinions from the findings of the last year university students' answers to the question "What are the positive and negative aspects of the equipment used in education?". 8 students put forward their negative aspects. 
As a positive opinion, they stated that technological tools provide effective learning (32), sharing entertaining content (27) and perpetuating learning by providing interaction (13). 3 students gave the answer themed self-confidence. To the question of how technological tools provide self-confidence, the students stated that they increased their self-confidence by providing the opportunity to make presentations and that they realized the way of addressing in a crowded environment. They stated that the students' responses to the negative aspects of technology-supported equipment in education may be due to the inadequate technological knowledge of the instructor (7), and if the use of technological equipment is not provided correctly, it may create distraction in students (1).

Some of the student views were as follows:

"The use of technological equipment both facilitates our learning and makes lessons enjoyable. We constantly use technological tools in daily life. Online trainings, effective presentation contents, video lectures, learning-based e-learning applications make it easier for us to learn and gain knowledge. "

"Our teachers' not knowing the use of technological equipment at a sufficient level can cause disconnection from the lesson. If I want to explain this with an example; One of the students helped a teacher who did not know how to use the project tool. We started the lesson 20 minutes late. Teachers have many new technological tools beyond the usual tools. They can train by using these tools such as kahoot, zoom, classroom, online exam system, etc. while lecturing.

\section{Discussion and Conclusion}

The innovation (29), communication (24), easy accessibility (15), technological tools (7) given by the senior university students to the question of "what is technology" were themed. This result obtained from the students revealed that the concept of technology is perceived correctly. Technology is among the sine qua non of today, and they cited technology as a tool that should be known as keeping up with innovation.

It was concluded that the students mostly used technology for communication. They stated that they mostly used the results of this question for communication (45), for the game (18), for obtaining information (10), and when preparing homework (2). This result is thought provoking. When used correctly, technology contributes to us. Technology has an important place in all areas of professions. Usually areas of use should not be games.

Findings related to the answers given by the senior university students to the question "Technological tools they have used in education until now" highlighted computer (50), projection device (45), presentation (40), tablet (15). The majority of the students stated that they used computers and projectors. According to the answers of this question, one more question was asked to the students: What the effect of using technological equipment on students is. Almost all of the students answered the question that they were motivated by the lesson (62). There were 35 students who stated that technological tools embody knowledge, making it easier for them to learn. 
When we look at the results of the final year university students' finding "What are the positive and negative aspects of the equipment used in education", there are 75 students who expressed a positive opinion. 8 students answered their negative aspects. As a positive opinion, the result is positive because technological tools provide effective learning (32). Effective learning transfers knowledge to cognitive memory correctly. Scientists' processes of structuring scientific knowledge involve proving, evaluating and presenting claims, and this also forms the cognitive infrastructure of argumentation [11]. For this, technology provides convenience in transferring the information to permanent memory by concretizing the information as a suitable tool in education. They stated that sharing fun content (27) makes learning permanent by providing interaction (13). 3 students gave the answer themed self-confidence. Considering the results of this finding, it is consistent with other studies.

They stated that the students' responses to the negative aspects of technologysupported equipment in education were due to the inadequate technological knowledge of the instructor (7), and if the use of technological equipment was not provided correctly, it could create distraction in students (1). One of these categories is special field information, mastering the basic concepts and content of the special field that the teacher will teach [14, 19]. Another is the general knowledge of the profession, that is, how the teacher will teach. Recognition of students, material development, classroom management, strategy and methods assessment and evaluation, etc. It includes knowledge and skills [1].

\section{$5 \quad$ References}

[1] Akbaşl1, S., Altun, T., Argon, T., Birel, F., Elma, C., Ergen, H., Genç, S. vd. (2009). Eğitim bilimine giriş. (Editör: Kasım Kıroğlu ve Cevat Elma). Ankara: Pegem Akademi. https://doi.org/10.14527/9786055885946

[2] Hamdi, M. \& Hamtini, T.M., (2016). Designing an Effective e-Content Development Frame- work for the Enhancement of Learning Programming. Int. J. Emerg. Technol. Learn. 11: 131. https://doi.org/10.3991/ijet.v11i04.5574.

[3] Alipour, M., \& Tajfar, S. (2019). Investigating (Im)politeness in online forums between English speakers and English as a foreign language learner. Global Journal of Foreign Language Teaching, 9(3): 137-156. https://doi.org/10.18844/gjflt.v9i3.4205

[4] Alja'am, J. M., El-Seoud, S. A., \& Mwinyi, M. U. (2017). Design and Implementation of a Multimedia-based Technology Solution to Assist Children with Intellectual Disability to Learn. International Journal of Emerging Technologies in Learning, 12(4): https://doi.org/ $\underline{10.3991 / \text { ijet.v12i04.6698 }}$

[5] Ateş, A., \& ALTUN, E. (2008). Bilgisayar Öğretmeni Adaylarının Uzaktan Eğitime Yönelik Tutumlarının Çeşitli Değişkenler Açısından İncelenmesi. Gazi University Journal of Gazi Educational Faculty (GUJGEF), 28(3). https://doi.org/10.17556/erziefd.305902

[6] Demir, S., \& Bozkurt, A. (2011). İlköğretim matematik öğretmenlerinin teknoloji entegrasyonundaki öğretmen yeterliklerine ilişkin görüşleri. İlköğretim Online, 10(3), 850-860. https://doi.org/10.17051/io.2014.19504

[7] Dirin, A., Laine, T. H., \& Alamäki, A. (2018). Managing emotional requirements in a context-aware mobile application for tourists. International Journal of Interactive Mobile Technologies (iJIM), 12(2): 177-196. https://doi.org/10.3991/ijim.v12i2.7933 
[8] Devedzic, V., \& Devedzic, M. (2019). Technology-Enhanced Assessment at universities and in schools: An initiative. International Journal of Learning and Teaching, 11(3): 8998. https://doi.org/10.18844/ijlt.v11i3.4319

[9] Eguz, S. (2020). Availability of virtual museum applications in courses based on the views of classroom teachers. Cypriot Journal of Educational Sciences, 15(2): 194-207. https:// doi.org/10.18844/cjes.v15i2.4501

[10] Fong, B., Fong, A. C. M., \& Li, C. K. (2011). Telemedicine technologies. Information Technologies in Medicine and Telehealth.

[11] Garcia-Mila, M., \& Andersen, C. (2007). Cognitive foundations of learning argumentation. In S. Erduran \& M. P. Jimenez-Aleixandre (Eds.), Argumentation in science education: Perspectives from classroom-based research (pp. 29-45). New York, NY: Springer. https:// doi.org/10.1007/978-1-4020-6670-2_2

[12] Gorder, L. M. (2008). A study of teacher perceptions of instructional technology integration in the classroom. The Delta Pi Epsilon Journal, 50(2): 63-76.

[13] Inaltekin, T. (2020). Examining secondary students' perceptions of the technology-based learning and teaching in science courses. World Journal on Educational Technology: Current Issues, 12(2): 71-83. https://doi.org/10.18844/wjet.v12i2.4628

[14] Konst, T., \& Kairisto-Mertanen, L. (2019). Developing innovation pedagogy. Contemporary Educational Researches Journal, 9(3): 74-84. https://doi.org/10.18844/cerj.v9i3.4224

[15] Konur, K. B., Sezen, G., \& Tekbıyı, A. (2008). Fen ve teknoloji derslerinde yapılandırmacı yaklaşıma dayalı etkinliklerde öğretim teknolojilerinin kullanılabilirliğine yönelik öğretmen görüşleri. In Eskişehir, Türkiye: The 8th International Educational Technology Conference.

[16] Köseoğlu, P., Yılmaz, M., Gerçek, C. ve Soran, H. (2007). Bilgisayar kursunun bilgisayara yönelik başarı, tutum ve öz yeterlik inançları üzerine etkisi. Hacettepe Üniversitesi Eğitim Fakültesi Dergisi, 33, 203-209. https://doi.org/10.21764/maeuefd.409368

[17] Kuimova, M., Uzunboylu, H. \& Pavlenko, B. (2017). Webquest as a way to enhance learning outcomes in foreign language classes, INTED2017 Proceedings, pp. 580-584. https://doi.org/10.21125/inted.2017.0272

[18] Lane, C. A. ve Lyle, H. F. (2010). Obstacles and supports related to the use of educational technologies: the role of technological expertise, gender, and age. Journal of Computing in Higher Education, https://doi.org/10.1007/s12528-010-9034-3

[19] Mendelli, S. (2019). Determination of mathematics teachers' opinions related to response and solution-based software in secondary education institutions. Global Journal of Information Technology: Emerging Technologies, 9(2): 41-50. https://doi.org/10.18844/gjit.v9 $\underline{\mathrm{i} 2.4421}$

[20] Porcello, D., \& Hsi, S. (2013). Crowdsourcing and curating online education resources. Science, 341(6143): 240-241. https://doi.org/10.1126/science.1234722

[21] Premkumar, G., \& Roberts, M. (1999). Adoption of new information technologies in rural small businesses. Omega, 27(4): 467-484. https://doi.org/10.1016/s0305-0483(98)00071-1

[22] Rosenau, J. N., \& Singh, J. P. (Eds.). (2002). Information technologies and global politics: The changing scope of power and governance. SUNY Press.

[23] Salama, R., Uzunboylu, H., \& Alkaddah, B. (2020). Distance learning system, learning programming languages by using mobile applications. New Trends and Issues Proceedings on Humanities and Social Sciences, 7(3): 23-47. https://doi.org/10.18844/prosoc.v7i2.5015

[24] Salama, R., Uzunboylu, H., \& El Muti, M. (2020). Implementing online questionnaires and surveys by using mobile applications. New Trends and Issues Proceedings on Humanities and Social Sciences, 7(3): 48-70. https://doi.org/10.18844/prosoc.v7i2.5016 
[25] Saldamlı, A. (2008). İnsan kaynakları yönetiminde bilişim teknolojisinin kullanımına yönelik bir araştırma: Tekirdağ örneği.

[26] Sang, G., Valcke, M., Braak, J. V. ve Tondeur, J. (2010). Student teachers' thinking processes and ICT integration: predictors of prospective teaching behaviours with educational technology. Computers \& Education, 54: 103-112. https://doi.org/10.1016/j. compedu.2009.07.010

[27] Seferoğlu S. S., Akbıyık, C. ve Bulut, M. (2008). İlköğretim öğretmenlerinin ve öğretmen adaylarının bilgisayarların öğrenme/öğretme sürecinde kullanımı ile ilgili görüşleri. Hacettepe Üniversitesi Eğitim Fakültesi Dergisi, 35: 273-283. https://doi.org/10.17679/iue fd. 58218

[28] Tekin, M., Zerenler, M., \& Bilge, A. (2005). Bilişim teknolojileri kullanımının işletme performansına etkileri: lojistik sektöründe bir uygulama.

[29] Tezer, M., Yildiz, E. P., \& Uzunboylu, H. (2018). Online authentic learning self-efficacy: a scale development. Quality \& Quantity, 52(1): 639-649. https://doi.org/10.1007/s11135$\underline{017-0641-1}$

[30] Walker, L. (2010). A phenomenological investigation of elementary school teachers who successfully integrated instructional technology into the curriculum. Unpublished Doctoral Dissertation, Walden University, Minnesota.

[31] Wang, G., Qin, L., Li, G., \& Chen, L. (2009). Landfill site selection using spatial information technologies and AHP: a case study in Beijing, China. Journal of environmental management, 90(8): 2414-2421. https://doi.org/10.1016/j.jenvman.2008.12.008

[32] Woodard, B. S. (2003). Technology and the constructivist learning environment: implications for teaching information literacy skills. Research Strategies, 19(3-4): 181-192. https://doi.org/10.1016/j.resstr.2005.01.001

[33] Yengin, I., Karahoca, A., Karahoca, D., \& Uzunboylu, H. (2011). Deciding which technology is the best for distance education: Issues in media/technology comparisons studies. Procedia Computer Science, 3: 1388-1395. https://doi.org/10.1016/J.PROCS.20 $\underline{11.01 .020}$

[34] Yilmaz, I., Ulucan, H., \& Pehlivan, S. (2010). Beden egitimi ogretmenligi programinda ogrenim goren ogrencilerin egitimde teknoloji kullanimina iliskin tutum ve dusunceleri. Ahi Evran Universitesi Egitim Fakultesi Dergisi, 11(1): 105-118. https://doi.org/10.16916/ $\underline{\text { aded.04927 }}$

[35] Yavuz, S., \& COŞKUN, E. A. (2008). Sınıf öğretmenliği öğrencilerinin eğitimde teknoloji kullanımına ilişkin tutum ve düşünceleri. Hacettepe Üniversitesi Eğitim Fakültesi Dergisi, 34(34): 276-286. https://dergipark.org.tr/tr/pub/hunefd/issue/7802/102261 https://doi.org/ $\underline{10.17556 / j e f .57076}$

[36] Hennink, M., Hutter, I., \& Bailey, A. (2020). Qualitative research methods. SAGE Publications Limited.

\section{Authors}

Vasfi Tugun was born in Kyrenia in 1988. After completing his primary education in Karaoğlanoğlu Primary School, he completed his secondary education in Anafartalar Lice and Lapta Yavuzlar Lice. He completed his degree in Near East University, Education Faculty in Computer Education and Instructional Technology in 2009. In 2011 after completing his master's degree also in Near East University Computer Education and Instructional Technology and then completed his $\mathrm{PhD}$ in the 
same department in 2015. After teaching as a part-time between 2009-2011 in Computer Education and Instructional Technology he has been teaching full-time since 2011 until present as a research assistant. He worked as a full-time research assistant between 2011-2015 and was appointed as a doctoral lecturer in 2015. He is single and knows English as a foreign language.vasfitugun@gmail.com

Almira R. Bayanova is a Postgraduate Student of the Institute of Psychology and Education at Kazan (Volga region) Federal University (18 Kremlyovskaya Street, 420000, Kazan, Russia). Her research interests are connected with the problem of a higher education teacher' competitiveness development, and formation of his hard-, soft- and self-competencies. She has more than 30 published scientific works in Russian and international journals, indexed by Scopus and Web of Science data bases. Email: almira-djl@mail.ru

Klavdiya G. Erdyneeva is a Doctor of Education, Professor, Head of the Department of Pedagogy at Transbaikal State University (30 Aleksandro-Zavodskaya Street, 672030, Chita, Russia). She is also an Academician of the International Academy of Sciences of Pedagogical Education, Honorary Worker of Higher Professional Education of the Russian Federation. Her research interests are connected with the psychological and pedagogical foundations of health-preserving activity, genesis and theoretical and methodological foundations of pedagogy and psychology of vocational education. She has more than 100 published works in Russian and International journals. E-mail: eridan58@mail.ru

Nikolay A. Mashkin is a Doctor of History, Professor of the Department of State and Legal Disciplines at Plekhanov Russian University of Economics (36 Stremyannyi Pereulok, 115093, Moscow, Russia). He is well known in Russia with his scientific works dedicated to the different problems of business law, commercial law and corporate right. He has more than 50 articles published in international journals and conferences materials. E-mail: Mashkin.NA@rea.ru

Zavgaria M. Sakhipova is $\mathrm{PhD}$ in Cultural Studies, Associate Professor of the Department of Foreign Languages at Almetyevsk State Oil Institute (2 Lenin Street, 423458, Almetyevsk, Russia). Her research interests for the last decade have been connected with project work and as well as problems of teaching English to students of non-linguistic universities. She has more 70 articles published in Russian and international journals. E-mail: $\underline{\text { sawgarija@mail.ru }}$

Liubov V. Zasova, $\mathrm{PhD}$ in Sociology, Associate Professor of Economics and Management Department at the I.M. Sechenov First Moscow State Medical University (Sechenov University) of the Ministry of Healthcare of the Russian Federation (8 Trubetskaya St., 119991, Moscow, Russia). Her main scientific and professional interests are connected with Development of educational processes and a quality of higher education. E-mail: 1vzasova@mail.ru

Article submitted 2020-09-13. Resubmitted 2020-10-10. Final acceptance 2020-10-10. Final version published as submitted by the authors. 